\title{
収穫装置と視覚認識に着目したトマト自動収穫ロボットの構成法
}

\author{
矢 口 裕 明*1 長谷川 貴 巨*2 長 濱 虎太郎*1 稲 葉 雅 幸*1
}

\section{A Research of Construction Method for Autonomous Tomato Harvesting Robot focusing on Harvesting Device and Visual Recognition}

\author{
Hiroaki Yaguchi*1, Takaomi Hasegawa*2, Kotaro Nagahama*1 and Masayuki Inaba*1
}

\begin{abstract}
In this paper we propse a construction method of autonomous tomato harvesting robot. For tomato harvesting we focus to harvesting device and visual recognition method. We propose 2 types of harvesting method; cutting scissor and rotational plucking gripper. For recognition, we compare different 3 types of 3D camera, then we construct tomato fruit recognition method using color detection and sphere shape fitting, and also propose tomato pedicel detection method by robust estimation using direction from center of fruit to pedicel and gradient orientation of pedicel edge. Combining these elements, we construct some autonomous harvesting systems and evaluate harvesting of real tomatoes in the tomato robot competition and the real farming veniel house. According to evaluation results, both cutting and plucking has different advantage and disadvantage, it is important to select appropriate one for breed or individual. Also for recognition, pedicel recognition, which must be broken, increases reliability harvesting.
\end{abstract}

Key Words: Agricaltural Robotics, Tomato Harvesting

1. 序論：なぜロボットによるトマト自動収穫が必要とさ れているのか

本論文ではトマト自動収穫ロボットに関する取り組みについ て述べる，そのためにはまずトマトについて論じる必要がある.

第一に，トマトの栽培がどのように行われているのかを述べ る.トマト栽培に扔いてはオランダにおける取り組みを参考と すると, 池田 [1]によればトマトを生産する一連の工程をシス テム化し高い生産性を達成している.この実現のためには計算 機によるデータ分析と温度, 湿度, 日照量などの環境制御や口 ボットによる搬送の自動化といった技術も利用されている. 耕 作地の少ない日本に拀いてもこのような取り組みに追随し, 収 量を増やす取り組みが行われている [2].

第二に，なぜトマトを収穫するのかについて述べる，先に述 べたような生育の自動化，機械化がなされるのであれば収穫も その流れで自動化できるのではないか，と考えられる向きもあ るかも知れないが, 現在収穫作業は人手で行われている. これ は果実が規格化された工業製品ではなく, 果実の形状や生え方 が一つ一つ異なり, 熟度や傷などを考慮した収穫判定などその 場で個別対応すべきことが多いからである.

原稿受付 2017 年 9 月 28 日

*1 東京大学

$* 2$ 株式会社デンソー

${ }^{* 1}$ The University of Tokyo

${ }^{* 2}$ DENSO Corporation

ロ 本論文は有用性（システム設計・構築分野）で評価されました.
第三に, 現状の課題である. 先に述べた収穫における問題点 を解決するにはより工業製品に近い，規格化された果実が生産 されればよいのではないか，と考えられる向きもあるかも知れ ないが, 三輪 [2]によるとオランダにおけるトマト栽培では工 業然とした農業を推進した結果, 過度な集中により多様性が失 われ，トマトの品種がごく少品種に絞りこまれたことが大きな 問題である. 一方で日本の国土が南北に長く多様な気候を持つ こと, また消費者の多品種で質の高い野菜を求める姿勢も重要 であるとの観点から, 今後も品種や個体ごとに個別の対応が求 められる傾向にあると考えられる。

最後に，ロボット投入の必要性である。これだけ個別対応す べき点が多いのであれば今後も人手で行えばよいのではないか， と考えられる向きもあるかも知れないが，トマトに適した環境 が人間にとって適した環境であるとは限らない. 文献 [1]によれ ば八ウス内に入射する光量は多いほうがよく，また八ウス内の 湿度は $25^{\circ} \mathrm{C}$ で $75 \sim 85 \%, 30^{\circ} \mathrm{C}$ で $85 \sim 90 \%$ が求められる. 日 本の夏は日中 $30^{\circ} \mathrm{C}$ を超えることが普通であり, 熱中症予防指

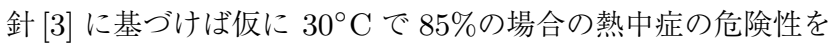
示す WBGT 值は $31^{\circ} \mathrm{C}$ となり，これは「危険」とされている. つまり，トマトの生育環境下で人間が労働することは危険であ り，ロボット投入による無人化が求められる.

以上の観点から我々は人間の代理となりうる農作業ロボット の実現に向けて，現在人間が手で行っているトマト収穫をその まま模擬するような形でのトマト自動収穫ロボットについて取 り組んできた $[4] 〜[7]$. 本論文では複数の収穫手段と視覚センサ 
および認識手法を組み合わせた三種類のロボットシステムにつ いて，ロボット競技会と実ほ場において実物のトマトを用いた 評価実験を行った結果を通じてトマト自動収穫ロボットの構成 法について述べる.

\section{2. 農作物の収穫に関する関連研究}

農業はすなわち食料の確保であり，種の存続に欠かせない取 り組みであるから，当然他の自動収穫に関する取り組みも長く 行われてきている. Bachche [8] によるサーベイによると収穫口 ボットの基本的なストラテジーは収穫, 認識, 移動の三つに分 けられる、移動は一般的な移動ロボットの技術が応用できるこ とと, 建屋そのものが農業に特化して設計された非常によく整 備されたものであり，現状でも温水管を畧間のガイドレールと して利用する機器が用いられている．移動に関しては既存技術 と農場内インフラの工夫により解決を図るものとして，収穫と 認識に着目する.

収穫システムについては, Blanes et al. [9] のサーベイによると 主に空気圧, 接触式, その他に分類される. Monta et al. [10] は吸 引ともぎ取り式のトマトの収穫機構について提案した. Bachche et al. はハサミ [11] や電熱カッター [12] を用いた切断機構を提 案している，パナソニックのトマト収穫ロボット $[13]$ は果実と 茥を押さえつけて引き離すことでもぎ取る方式を提案している。 これら収穫方法を改めて分類すると，もぎ取りと切断の二つに 分けられるが，この方式の違いは対象となる植物の特性にもよ るため，改めて対象物の考察を要すると考える。

認識システムについては, Bachche [8] によるとカラーカメラ とマルチスペクトルカメラの二つに分類している.このうちマ ルチスペクトルカメラはコストが非常に高いため除外して考え る. Kondo et al. [14] は偏光フィルタ付きのステレオカメラと 照明を用いたトマトの房の認識を行った. Jiang et al. [15] はス テレオカメラと色抽出を用いたトマトの果実認識を行った. Guo et al. [16] は果実の色と形状の対称性に基づくいちごの果実と果 柄の認識を行った.これらの先行研究では果実の特徵に基づい た認識手段を選択しており，例えばトマトといちごではカラー 画像の色特徴が有効であることを示している.

\section{3. トマト自動収穫の方法論}

\section{1 トマト果実について}

トマトを収穫するにあたり，トマトの栽培のされ方，生物と しての特徴に注目する。実際のトマトほ場の様子を Fig. 1 に 示す。ほ場ではトマトの樹が列をなして配置されており，列に 沿って温度調整のための温水配管が設置されている。この温水 配管は移動用のレールを兼ねており，生育監視装置や運搬設備 の移動の他，提案する収穫ロボットでも移動に用いる。

大玉トマトの場合，トマト果実が複数個密集した房を形成し， その房は主茎上に等間隔に配置される。主茎はお抄よそ鉛直方 向に向かって伸びており，生育が進むに連れて管理工程におい て配置の最適化が行われる。この最適化はあくまで人力で果実 の収穫を行うことを考慮した際にちょうど良い高さとしている ものである。また同時に生育の観点から管理工程では葉かきが 行われ，果実周辺の葉は除去された状態で収穫を行うこととな

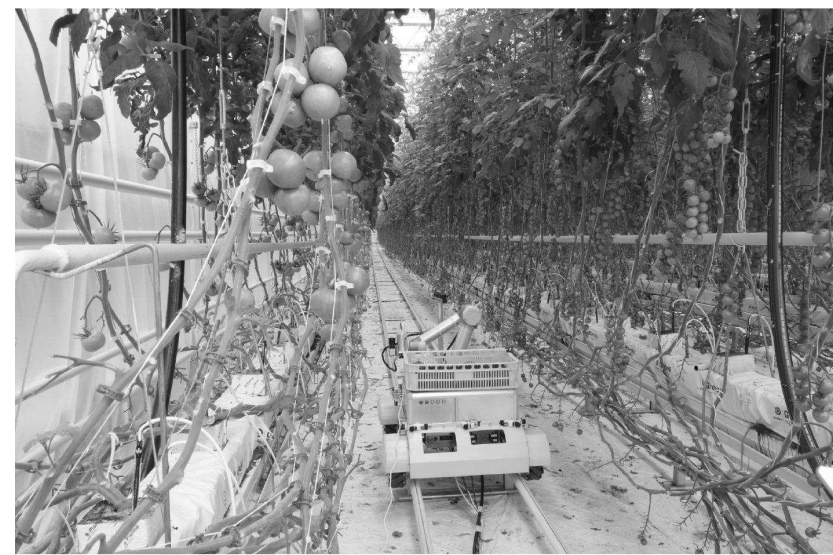

Fig. 1 Tomato farming veniel house

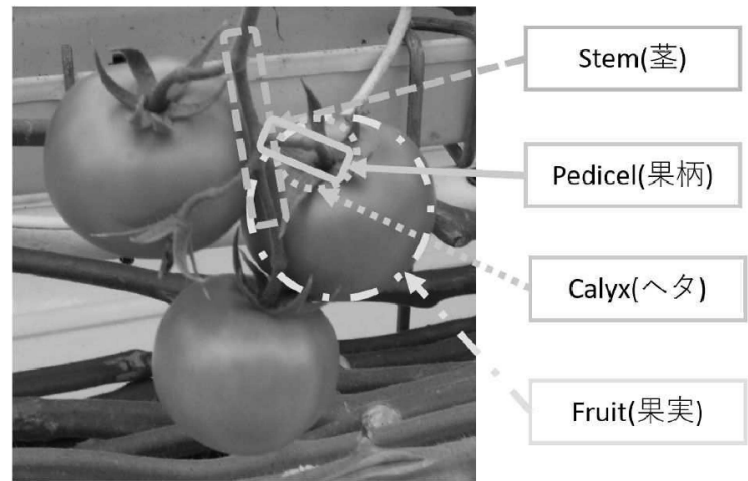

Fig. 2 Construction of tomato [7]

る、このことから実ほ場においても果実を葉が覆い隠すようこ とで認識や収穫が阻害されることは起こりにくい.

Fig. 2 に示すように一つの房に着目すると，房に生った複数 個の果実は主茎から分岐した茎に対して 1 個ずつ，果柄とよば れる小茎を通じて生えている，人手による収穫の際にはこの果 柄を切断やもぎ取るなどの方法で破壊して果実を分離する.

\section{2 果実自動収穫の方法論}

これらの特性と先行研究を踏まえ, 本論文においては果実収 穫の方法について以下の要素に着目する.

収穫方法については，切断ともぎとりの二つの手段を比較検 討する。トマトの果実はある程度の強度を持ち，手で握った程 度では破損しないため，もぎとりが可能である．また果柄も切 断のための刃物が入る余地のある大きさとなっている，そのた めどちらの手段を使っても問題なく収穫ができるため，収穫時 間や果実の破損可能性を比較することが可能である.

認識方法については，まず果実に着目する。トマト果実は収 穫時期を迎えると赤くなり，かつ同一品種であれば一定の大き さに成長するため，認識は比較的容易であると考えられる．次 に果実が植物体に対して接続されている部位である果柄に着目 する，果柄は周囲の植物体と同色でかつ果実と比較して小さく 認識は比較的難しいと考えられる.

さらに，ロボットシステムの要素として，特にビジョンセン サの方式と取り付け位置について着目する。実ほ場を考えた場 合，室内環境に比べて外乱が大きく，ロバストなセンサが求め 


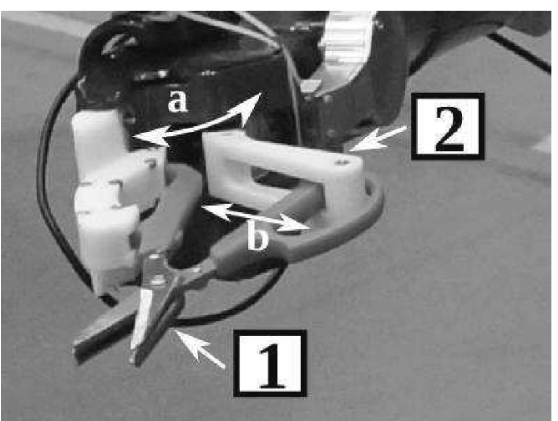

Fig. 3 Harvesting scissor [5]

られる。また認識対象の大きさや，認識範囲を㽞とするか房や 果実とするかにより，全体を観測すべきか，あるいはエンドエ フェクタの状況に注目すべきかが異なるため，ロボットのどこ にセンサを取り付けるかも重要な要素となる.

一方で各要素について収穫手段により求められる認識手法が, また認識手法によりビジョンセンサの必要条件が決まることが 予想されるため, これらの要素を適宜組み合わせることで複数 回評価実験を行い，収穫システムの構成法を提案する.

\section{4. トマト果実の収穫方法}

先に述べたとおり，トマト果実収穫には切断ともぎ取りの二 つの収穫方法が考えられる。切断方式は刃物で果柄を切断する ものであり，人間の場合ははさみやナイフを用いる。 もぎ取り 方式は人間の場合手のひらで果実を包み込み, 親指と人差し指 で果柄の節になっている部分をつまみ，ひねることで節を破壊 する。ロボットにおいてもこの 2 方式を踏襲することとし，そ れぞれの方式のエンドエフェクタを提案する.

\section{1 補助グリッパー付きはさみによる切断収穫}

刃物を用いた切断を考えた場合，切断された果実を保持する 手段も考える必要がある。これは人間でも同様であるが，はさ みの刃の下にばねで動作するグリッパを持つ園芸用のはさみが 市販されている。これを用いることではさみの開閉動作を行う だけで切断と保持を行うことができる. Fig. 3 は市販のはさみ をロボットのフィンガーで操作する治具を作成したもので，ロ ボットのフィンガーの開閉に連動してはさみの刃を開閉するこ とができる. 収穫の模式図を Fig. 4 に示す. はさみの刃が閉じ た時に果柄は切断されるが，その直下にあるグリッパがばねで 押さえつけることで果実を保持する. 刃を開くとグリッパも開 き，果実をはなすことができる.

\section{2 無限回転ハンドによるもぎ取り収穫}

はさみハンドの場合ははさみの刃の間に果柄が正確に入る必 要があり, 認識精度が求められていたが, もぎ取りハンドの場 合ある程度果柄の方向がずれても実がつかめれば収穫が可能で あり，認識誤差に対してロバストである.

Fig. 5 にハンドの写真を示す. ハンドは二自由度となってお り, 開閉と無限回転が可能である. 収穫の模式図を Fig. 6 に示 す. 収穫の際には開閉式の爪で果実をつかんでから全体が回転 することで果柄がもがれ，へ夕付きの果実をもぎ取ることがで きる，回転軸と果柄の軸は必ずしも一致する必要はないが，近

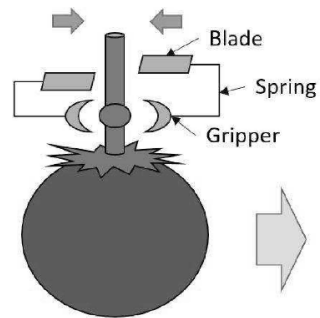

(1) Approach

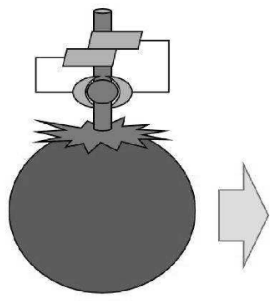

(2) Cut Off

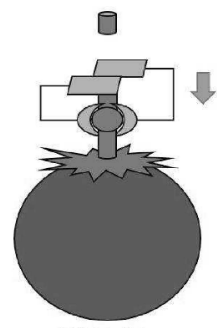

(3) Hold
Fig. 4 Image of Cutting

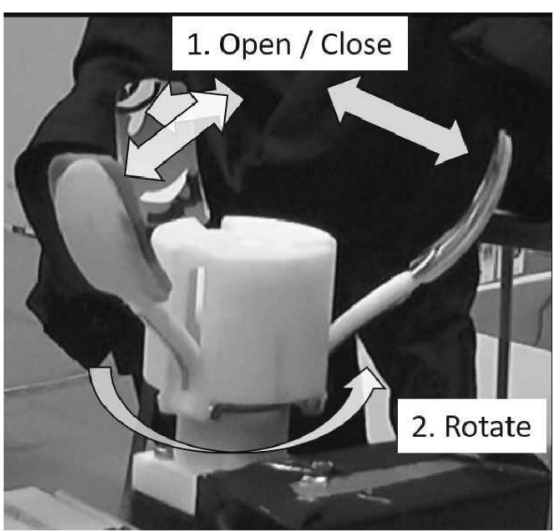

Fig. 5 Tomato Plucking Hand [6]

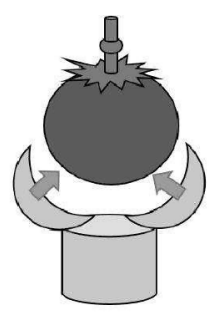

(1) Grasp
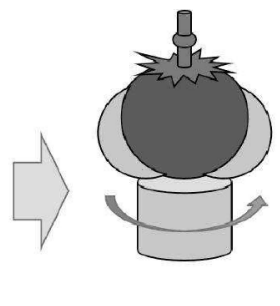

(2) Rotate

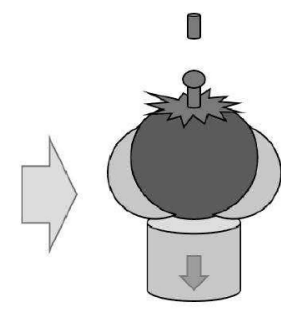

(3) Pluck Off
Fig. 6 Image of Plucking [6]

いほうがより正確に果柄を破壊することができる。フフンガー の閉じる方向にはスプリングが入っており，把持力はスプリン グの力以上に発生しないために果実を傷つけるおそれが低い. 一方でフィンガーの開き角やモー夕負荷などから把持状態を推 定することはできない.

\section{5. 収穫のためのトマト認識}

収穫するにあたり，収穫対象である果実と，収穫の際の破壊 対象である果柄を認識する方法を考える.

\section{1 三次元カメラ}

収穫のための情報として，トマトは色特徴がはっきりしてい るが，加えて三次元情報を得ることで収穫のための動作計画が 容易となる. 求められる三次元カメラの条件として，1）距離情 報に対応した正確な色が取得できること，2）直射日光下の様 な極端な照明条件下でも動作すること，3）太さ $5[\mathrm{~mm}]$ 程度の 果柄を計測できること，の三つが挙げられる。この中で特に困 難なのは 2）と 3）である. 近年三次元カメラとして赤外線パ 
Table 1 Comparison between PlayStation Camera, Xtion PRO LIVE, and RealSense SR300

\begin{tabular}{|l|r|r|r|}
\hline Camera & $\begin{array}{r}\text { PlayStation } \\
\text { Camera }\end{array}$ & $\begin{array}{r}\text { Xtion } \\
\text { PRO LIVE }\end{array}$ & $\begin{array}{r}\text { RealSense } \\
\text { SR300 }\end{array}$ \\
\hline Resolution [px $\times \mathrm{px}$ ] & $640 \times 400$ & $640 \times 480$ & $640 \times 480$ \\
Frame Rate [fps] & 60 & 30 & 30 \\
Field of View [ $^{\circ}$ ] & 83 & 70 & 90 \\
Distance of Use [m] & $0.3-\infty$ & $0.8-3.5$ & $0.3-2.0$ \\
\hline
\end{tabular}

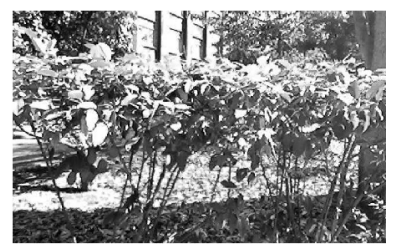

(a) Stereo Input Image

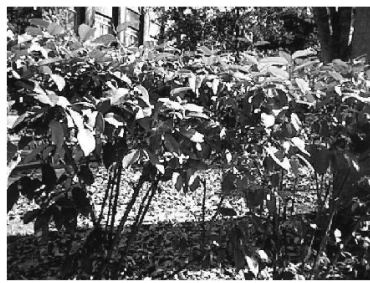

(c) IR Proj. Input Image

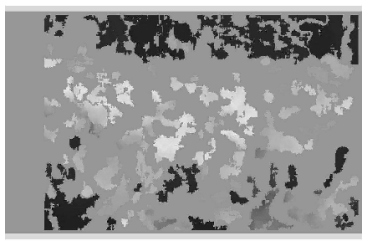

(b) Stereo Disparity

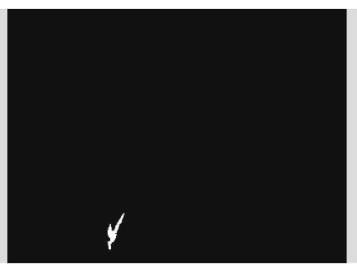

(d) IR Proj. Depth Image
Fig. 7 Comparison Stereo (PlayStation Camera) and IR Projection (Xtion PRO LIVE) 3D Camera In Outdoor [6]

ターン投光方式の Xtion PRO LIVE がよく用いられるが，こ の方式は直射日光に含まれる強い赤外線により散乱してしまう と計測不能となる。また太さ $5[\mathrm{~mm}]$ を計測するには解像度を 高くするか, 計測距離を近づけるかのどちらかになるが, 同じ くXtion ではどちらも満たすことができない.さらに農場の畧 間の距離を考慮した際の想定距離 $0.5[\mathrm{~m}]$ での計測ができるとい うことも必要となる. パナソニックのトマト収穫ロボット [13] ではこの条件を満たすような三次元カメラを独自に開発してい るが，本研究では市販のカメラを用いることとする.

本研究ではカメラの重量や接続の簡便さなどを考慮した結果, 1）ASUS Xtion PRO LIVE (赤外線パターン投光)，2）Sony PlayStation Camera (ステレオカメラ), 3) Intel RealSense SR300 (赤外線パターン投光), の三つのカメラを選定し, 比較 評価を行った. Table 1 に各カメラの諸元を示す. 解像度はお およそ同じとなるが，測距方法と計測可能範囲が大きく異なる.

まず, Xtion PRO LIVE と PlayStation Camera の比較を行 う. Fig. 7 に屋外環境下でのステレオカメラと赤外線投光カメ ラの比較を示す。このときの日向の照度は $75,000[\mathrm{~lx}]$, 日陰の照 度は $3,500[\mathrm{~lx}]$ であった. 距離計測結果はFig. 7 (b) と Fig. 7 (d) の着色部分で, 着色されていない部分は距離計測不能箇所であ る. ステレオカメラが主要な範囲を計測できているのに対し, 赤 外線投光カメラはほぼすべての範囲が計測不能であった，同様に Fig. 8 に $50[\mathrm{~cm}]$ カメラから離したダミートマトを計測した際 のステレオカメラと赤外線投光カメラの比較を示す. Fig. 8 (c) と Fig. 8 (a) に示すように二つのカメラの計測範囲はほぼ同じ であるが, 赤外線投光カメラは Fig. 8 (d) のようにトマトの果

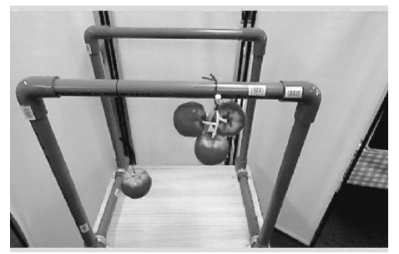

(a) Stereo Input Image

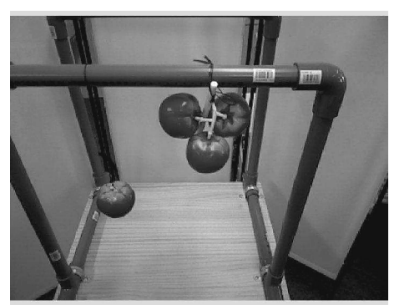

(c) IR Proj. Input Image

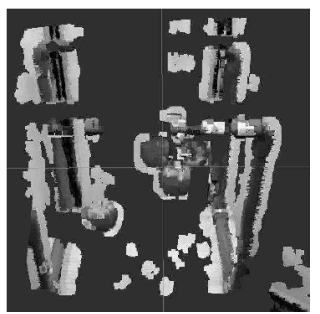

(b) Stereo Point Cloud

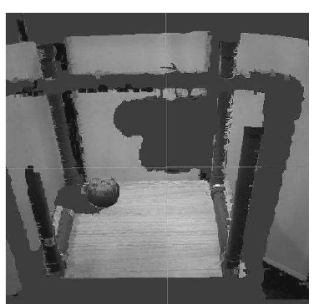

(d) IR Proj. Point Cloud
Fig. 8 Comparison Stereo (PlayStation Camera) and IR Projection (Xtion PRO LIVE) 3D Camera, Target objects are in $50 \mathrm{~cm}$ front of camera [6]

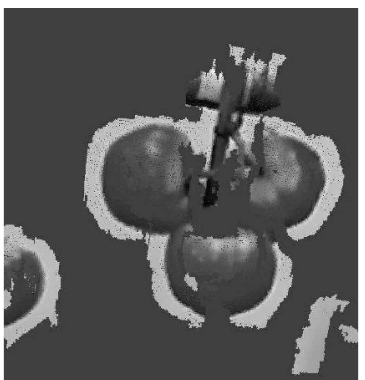

(a) Stereo camera: PlayStation Camera

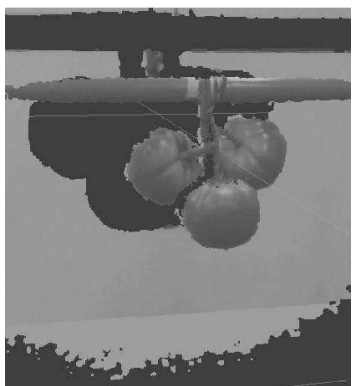

(b) IR projection: RealSense SR300
Fig. 9 Measurement of dummy tomato from $300[\mathrm{~mm}]$ distance

実が計測されていない. 一方ステレオカメラは Fig. 8 (b) のよ うにトマトの果実が計測されている.

次に PlayStation Camera と RealSense SR300 の比較とし て距離 $30[\mathrm{~cm}]$ からダミーを計測した結果を Fig. 9 に示す.ど ちらも距離計測は行われているが, ステレオカメラの方は果実 の一部がテクスチャが不足しており欠落があり，またエッジ付 近では背景も果実と同じ距離に計測されている．特に果柄部は ステレオでは欠落してしまっているが，SR300は果柄を計測で きていることが分かる.

これらの比較評価からトマト収穫センサとして以下の結論を 得る. 屋外の直射日光下で果実の認識を行うにはステレオ方式 の PlayStation Camera が適している. 一方果柄認識を行うた めには RealSense SR300により近接して計測することが適し ているが, 赤外線パターン方式の弱点である直射日光下での運 用にはシェードを用いるなどの対策が必要である。

\section{2 果実認識}

ステレオカメラ，赤外線パターン投光方式の違いによらず，三 次元カメラを用いて取得された色情報つき点群から果実認識を 行う手法を提案する. トマトの果実は球体に近く, さらに熟し 
た果実は赤いものと抒よそ仮定を置くことができる，この仮 定に基づいた場合，トマト果実をある一定の大きさの赤い球体 として近似することができ，また果実以外にこの条件に当ては まる物体がほ場に扔いては存在せず，仮に背景に別の房のトマ トが写り込んだ場合にも距離情報を用いて除外することが可能 であると考えられる。

まず色検出により，視野中の果実候補領域を検出する，この 時点では候補領域は房や果実ごとに分散していると考えられる ため, ユークリッド距離を用いて点群を分割する. 点群の分割に 際して, 赤外線パターン投光カメラの場合はステレオカメラに 比べ点数が増大する傾向があるためボクセル投票に基づくダウ ンサンプリングを行う．ただしダウンサンプリングによる点の 密度の低下を防ぐことと, 三次元カメラの点群の特徵である画 像座標中の画素の並びを維持するため, 投票時にどのボクセル にどの点を投票したかを記録しておき，点群を分割した後，そ の情報を元に画素の並びを維持したままアップサンプリングを 行う.

最後に分割されたすべての点群に対してRANSACによる球 体モデル当てはめを行う.モデルと点との計算は距離を利用し, 計算時間の短縮や外れ值の発生を考慮して球体のサイズはある 程度のサイズで限定する。最終的に当てはめられた球体と点の 法線を比較し, 球の法線から外れたものはフィッティングの結 果から除去する, 球に含まれなかった点群に対して繰り返し球 体当てはめを適用し，残り点数が少なくなるまで繰り返すこと で視野中のすべてのトマト果実を求める.

Fig. 10 に模造品のトマト果実を用いた入力点群を, Fig. 11 に果実認識の結果をそれぞれ示す，各果実ごとに領域が正しく 分割され，大きさも球体で近似されている。
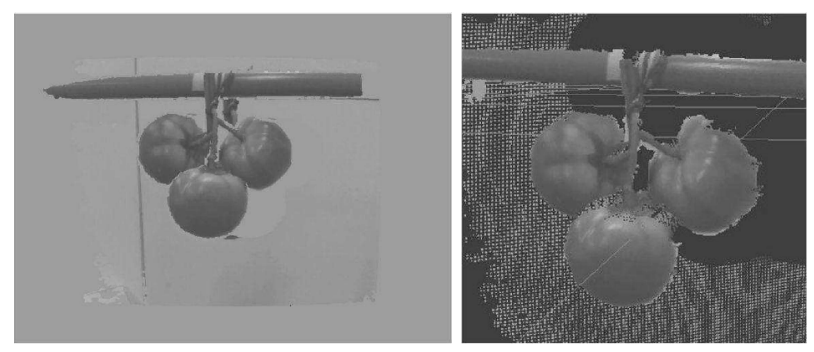

Fig. 10 Input 3D image. Right: RGB image, Left: Point Cloud [7]
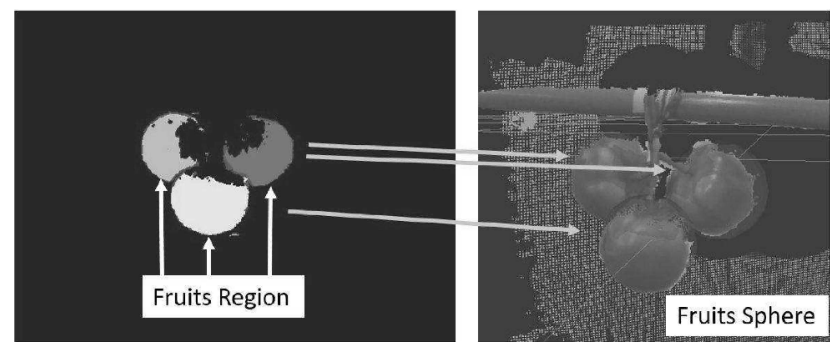

Fig. 11 Fruits detection. Right: labeled image, gray regions indicates region of fruits. Left: Point Cloud and detected fruits, are indicated as sphere [7]

\section{3 果柄認識}

前節で求めた果実の情報を元に，果柄認識を行う。果柄が見 えていることが前提となるため, RealSense SR300により取得 された密な点群に対して行うアルゴリズムを提案する. 最もカ メラから近い果実を収穫対象とし, 収穫対象果実の位置とサイ ズを用いて認識を行う。

まず，果実認識において果実候補領域とならなかった領域に 対して, 再度色抽出を行い, 緑色の領域を抽出する。 その領域 のうち, 対象果実の周囲にある領域を絞り込む. 果実は球体と して与えられているため, 球体表面から一定以内の距離に存在 する点を果柄候補として抽出する.

次に果柄候補となった点群に対して三次元エッジ検出を行う. 点群は画像上の画素の並びを保持した状態のため, 行列上に整 列している。 そのため画像処理で用いるようなボックスフィル 夕を用いてエッジ検出を行う。ここでは $\mathrm{z}$ 軸方向の距離を用い たラプラシアンフィルタを用いる.

得られた三次元エッジに対して，直線フィッティングを行う. ただし，得られた三次元エッジが構成する要素として，目的の 果柄以外にも未熟な果実, へ夕, 主茎など, 様々な部位が含ま れる，果柄の特徵として，果実に接続されているため，果実の 中心を通るような直線要素を含む確率が高い。逆に未熟な果実 や主茥は必ずしも果実を通らず，またへ夕は果柄と同一方向に 向いているため，混同しても問題とならないケースが多いと考 えられる。そこで直線フィッティングでは，果実の中心を通り， かつ多数のエッジ点を近傍に含むような三次元直線をロバスト 推定によって求める. 推定ではまず果柄の方向べクトル $v_{\text {pedicel }}$ を無作為に抽出したエッジ点の位置 ${ }^{i} p_{\text {edge }}$ の単純平均と対象果 実の中心 $p_{\text {fruits }}$ の差から求める. 各エッジ点の評価值 ${ }^{i} w$ を 求め, すべてのエッジ点について総和をとったものが果柄べク トルの評価值となる. $i$ 番めのエッジ点の勾配方向を ${ }^{i} v_{\text {edge }}$ と したとき， ${ }^{i} w$ は次式のように与えられる。

$$
\begin{aligned}
{ }^{i} w= & \exp \left(\left|{ }^{i} p_{\text {edge }}-\left(\left({ }^{i} p_{\text {edge }}-p_{\text {fruits }}\right) \cdot v_{\text {pedicel }}\right) v_{\text {pedicel }}\right|\right) \\
& \times\left(1.0-v_{\text {pedicel }} \cdot{ }^{i} v_{\text {edge }}\right)
\end{aligned}
$$

無作為抽出によるベクトル計算と評価值算出を何度か繰り返 して最大の評価值をとるような果柄べクトルを求め, 最後に得 られた果柄ベクトルから果柄の果実表面上の位置と方向を計算
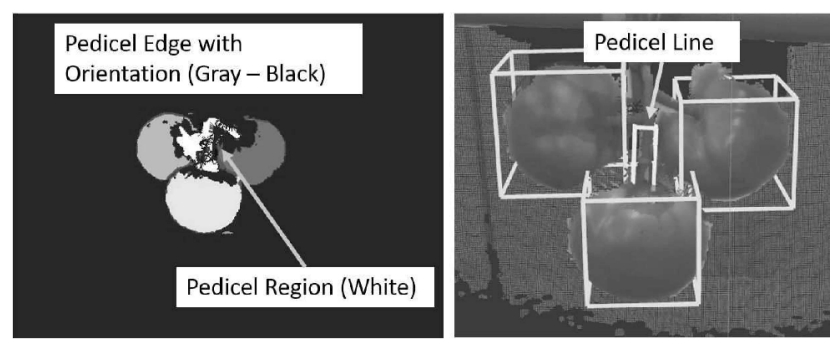

Fig. 12 Pedicel detection. Right: labeled image. White region indicates pedicel candidate points, and gray - black lines indicate extracted edge and its orientation of gradient. Lines are colored brighter if its weight is high. Left: Point Cloud and detected pedicel, is indicated as a cylinder [7] 
する.ロボットはこの情報を元にエンドエフェクタの姿勢を決 定する。

Fig. 12 に果柄認識の結果を示す. 図中中央の灰白色で示さ れている果実が対象となっている。図中白から黒色の線はエッ ジ点とその勾配方向を示しており，色は白色に近づくにつれて 評価值が高いことを示している. 白色で示されている果柄候補 領域には隣接する別の果実の果柄が含まれているが，そちらに 誘導されることなく対象果実の直上の果柄を検出できている.

\section{6. トマトを用いた収穫実験}

農作業支援をはじめとする，実環境で作業するロボットの開 発においては, ソフトウェアによるシミュレーションや模型を用 いた実験では，本質的な問題を見つけて取り組むことが難しい と考えられる。例えば, 農作物の枝の柔軟性や果実の隠れ, 収 穫時の果柄の機械強度などは, 実環境以外で表現し評価するこ とは難しい. 一方で，1台のロボットの実験のために実環境を準 備することは，特に植物を用いるような農作業支援夕スクにお いては，そもそも実際の商品と同じ生育環境が必要となり, 場 所と設備の用意, 生育にかかる日数や費用, 本来出荷されるべ き作物の価值損失など様々なコストの負担があり, 特に開発初 期段階において商品の棄損の恐れのある実験を長時間行うこと は非常に難しい.

そのような中, 2014 年から北九州学術研究都市で「トマトロ ボット競技会」が開催されている. トマトロボット競技会は, 農 作業を行うロボットのための技術開発の促進や興味の拡大を目 的として開催されている競技会である．競技会では，ロボット でトマト果実を収穫する際の速度や自律性, 正確性を競う。口 ボットは，スタート位置から操縦あるいは自律動作により移動 して, 10 分間の制限時間の中, 農園から提供された本物のト マト株から果実を収穫する，競技は三つのステージから構成さ れ, Stage 1: ラックから吊るされた 1 個の果実へのアプロー チ, Stage 2:ラックから吊るされた房にある複数の果実の収穫, Stage 3 : 実際の苗からの収穫, の三段階で行われる. ロボット が移動する際のレールの使用の有無, オペレータの操作の有無, そしてオペレータが操作する場合にはロボットを直接見るか否 かは選択することができ，それらの難易度と収穫果実数によっ て点数が決定される.トマトロボット競技会の詳細については, 文献 [17] あるいは競技会ホームページを参照されたい.

以上のように，トマトロボット競技会の競技は農園に近い環 境で，本物の農作物を用いて行われるため，実環境でのロボッ 卜実験の場として大変貴重なものとなっている. そこで筆者ら は，評価実験を競技会から実ほ場へと段階的に進めるアプロー チを取る、比較的ロボットの運用が容易であり，実物のトマト を使用しつつも商品の棄損に対する損失のない競技会を通じた ロボットプロトタイプの検証をまず行い, 競技会において有効 性が見込まれたものに関し，実ほ場において実際の生育環境化 で栽培された実物のトマトに対する評価実験を行うという方法 をとった。

Table 2 に本論文で評価した三つの収穫システムの比較を示 す.ロボットプラットフォームは実験を進めるにあたりより小 型のものを採用してきており，これによって動作ストロークが
Table 2 Comparison of robot system for each experiment

\begin{tabular}{|l|r|r|r|}
\hline Item & Exp. in 6.1 & Exp. in 6.2 & Exp. in 6. 3 \\
\hline Platform & HRP2 & UR5 & UR3 \\
End Effector & (Dual Arm) & $\begin{array}{r}\text { (Single Arm) } \\
\text { Plucking }\end{array}$ & $\begin{array}{r}\text { (Single Arm) } \\
\text { Scissor }\end{array}$ \\
\hline Head Camera & Xtion & PS Camera & - \\
Hand Camera & USB Camera & - & SR300 \\
Recognition & Teleoperation & Fruit & Fruit \& Pedicel \\
\hline Field & Competition & $\begin{array}{r}\text { Competition } \\
\text { Real Farm }\end{array}$ & Real Farm \\
\hline Time for & & & 10 \\
1 Fruit $[\mathrm{s}]$ & 60 & 23 & \\
\hline
\end{tabular}

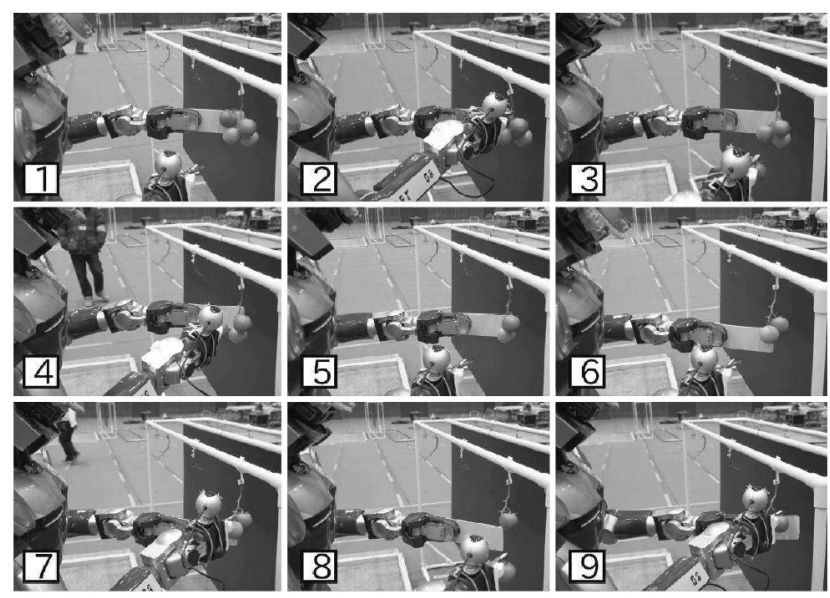

Fig. 13 Tomato harvesting by teleoperation with scissor hand [5]

短く，収穫時間を短縮することができている，認識機能につい ては果実認識から果柄認識へと細部に対する注目を行うことで 精度が向上しており，かつセンサの種類や取り付け位置も近接 に適したものへと遷移している。当初競技会においてプロト夕 イピングを行っていたものが，最終的に実ほ場における実験評 価ができる信頼性を獲得している.

\section{1 はさみハンドを用いた遠隔操縦収穫}

第 1 回トマトロボット競技会においてはロボットを用いたト マトの収穫の可能性を探るため, 既存のロボットプラットフォー ムに収穫用の装置を取り付けることで収穫システムのプロト夕 イピングを行うことを目標とした. ロボットシステムとして半身 ヒューマノイドロボット HRP $2 \mathrm{~V}$ に市販の収穫はさみをアタッ チメントを介して装着し, オペレータが手先の単眼ハンドアイカ メラと頭部の三次元カメラ Xtion PRO LIVE を用いて遠隔操縦 することで収穫を行う実験を行った. Stage 2 競技中に HRP2V で房からトマトを 1 個ずつ収穫した実験結果を Fig. 13 に示す. オペレータはロボットの頭部カメラとハンドアイカメラ画像の みを頼りに遠隔操縦を行ったが, 頭部カメラ画像を見ながら刃 先をおよその切断位置まで誘導し，ハンドアイカメラの画像を 見ながら細かい位置調整を行って，4 個のトマトを 1 個ずつ収 穫して箱に入れることが可能であった.

特に, ハンドアイカメラの画像は, 単に果実に近い距離から の画像として刃先の誘導に有効であっただけでなく, 刃先が果 柄に十分に深く入り，切断できる状態であるかどうかの判断に 
有用であった。 ハンドアイカメラはハサミの刃から少し横にオ フセットされた位置に搭載していたため，ハンドアイカメラか ら見た奥側の刃が果柄に十分隠れ，さらに枝が手前の刃に十分 隠れていることから，二つの刃の間に枝が入っていることが確 認できた.

このように，頭部カメラとハンドアイカメラのみの情報から オペレータが果実収穫を適切に行えたという結果は，これら二 つのカメラ画像を最小入力セットとした，画像処理による収穫 タスクの自動化の可能性を示していると考えられる. 一方で, 刃 が果実を傷つけた例が一例存在し，これは刃先の大きさが果実 や果柄に対して大きすぎることが理由としてあげられる，次の 課題として認識処理による自動収穫と果実へのダメージの回避 が挙げられる.

\section{2 もぎ取りハンドと果実認識を用いた自動収穫}

はさみを用いた収穫実験において問題となったのははさみの 刃が果実を傷つける可能性があることと，果実と果柄の認識を 行うための情報量が不足していることであった。そこで果実を 傷つける可能性が低く果柄の認識精度が低くても収穫できる装 置としてもぎ取り方式のハンドを作成し，Universal Robot 製 UR5 と全方位台車の組み合わせによる収穫ロボットを構築し た。台車上部，人間でいうと頭部に当たる部分に PlayStation Camera を設置し，これによる果実認識を用いた自動収穫シス テムについて第 2 回トマトロボット競技会において収穫評価を 行った.

Fig. 14 に, Stage 2 の競技中に実際の果実をフレームに吊 り下げたものを収穫する様子を示す. 1 個の収穫に $85[\mathrm{~s}]$ 程度 かかっているが, このうち $12[\mathrm{~s}]$ 程度がハンドの移動, $30[\mathrm{~s}]$ 程 度が果実をもぎ取るためのハンド回転，18 $[\mathrm{s}]$ 程度が収穫カゴへ のハンドの移動に費やされている。認識処理は $0.2[\mathrm{~s}]$ 程度であ り，ロボットの動作と比較して十分速い。また，競技中は 3 回 収穫に挑戦し，2 回収穫に成功したが，2 回ともへタがとれた. また 1 回の失敗はトマトのない場所へハンドを動かした空振り であった。

同様に Fig. 15 に Stage 3 の練習中の様子を示す。このトラ イでは 5 回中 3 回収穫に成功したが，3 回ともへタがとれた 失敗は空振りが 1 回と複数卜マトの重複把持が 1 回であった.

最後に実農場で収穫を行った，収穫の様子を Fig. 16 に示す。 競技会の実験は屋内で行ったのに対し，農場では直射日光下お よび榃間の狭い環境での収穫を行った. 直射日光下の植物が張 り巡らされた状況でも収穫を行うことができた。また農場の卜 マトは競技会のトマトよりも大きく茥が太く，へ夕の損傷はな かった.

収穫にかかった時間を計測するとほとんどがロボットの動作 に関する時間であり，すなわちもぎ取りのためのハンド回転と アームの動作に時間を費やしていた．特に競技会では果実の固 定方法が回転しやすいプラスチックバンドによるものであった ため，回転によるもぎ取り収穫に時間がかかっていたが，農場 での収穫実験では競技会の半分ほどの時間でもぎ取り収穫でき ている。これは果柄をもぎ取るまでのハンドの総回転数の違い によるもので，収穫するトマトの品種の違いに依存すると考え られる，農場で用いた品種を想定してロボットアームとハンド

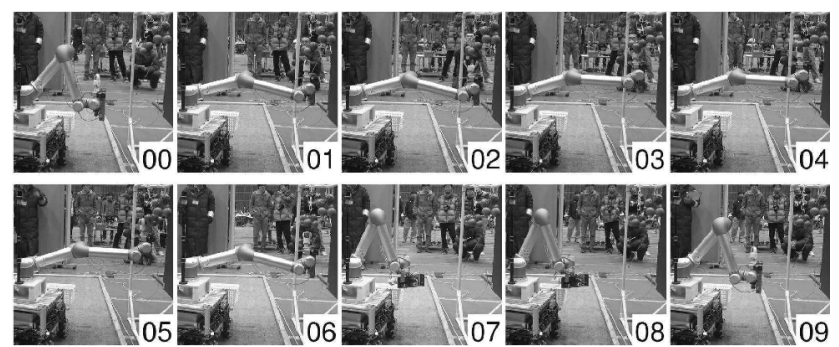

Fig. 14 Harvesting in Tomato Robot Competition Stage $2[6]$

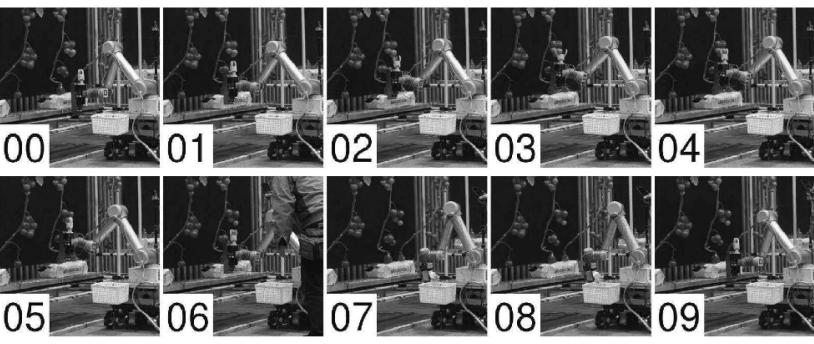

Fig. 15 Harvesting in Tomato Robot Competition Stage $3[6]$

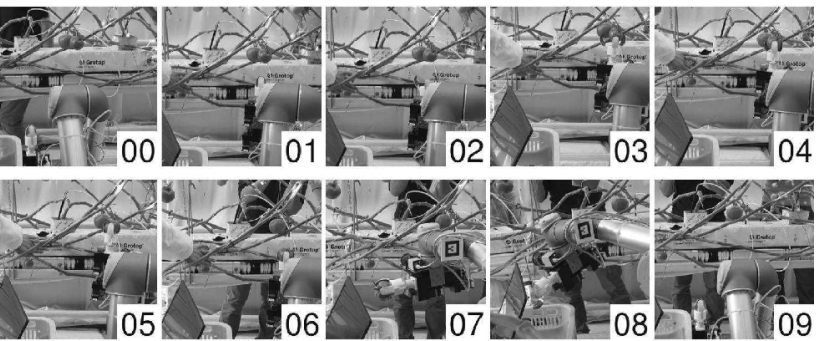

Fig. 16 Harvesting in Real Farm $[6]$

Table 3 Evaluation of harvesting time for plucking

\begin{tabular}{|l|r|r|r|}
\hline Item & Comp. [s] & Real Farm [s] & Improved [s] \\
\hline Fruit Recognition & 3 & 3 & 3 \\
Approaching & 12 & 12 & 4 \\
Putting & 18 & 19 & 8 \\
Hand Open/Close & 20 & 20 & 4 \\
Hand Rotation & 31 & 15 & 4 \\
\hline Total & 85 & 69 & 23 \\
\hline
\end{tabular}

開閉，回転の動作の高速化を行ったところ，最終的に 1 個あた り $23[\mathrm{~s}]$ での収穫が可能となった。一方で，提案する収穫シス テムにおいては収穫率が $5 / 8=62.2 \%$ 程度となった.この数字 は十分な数の母数がないため正確な評価結果ではない. 失敗例 の分析から少なくともより細かいトマトの認識と操作が必要で あり，収穫率向上のためには認識により時間をかけなければな らないと考えられる.

\section{3 はさみハンドと果実果柄認識を用いた自動収穫}

もぎ取り方式においては果実の破損が少ないことが分かった が，一方で果柄の切断までの時間の長さや品種によるへ夕の破壊 といった問題点も明らかになった。そこではさみ方式で果実を傷 つける可能性を低くするために小型化を行い，さらに新たに果柄 認識を実装した。はさみハンドをUR5よりも小型の Universal Robot 製 UR3 に搭載し，Intel RealSense SR300を手先に設 置し，果実果柄認識の組み合わせによるロボットシステムを構 


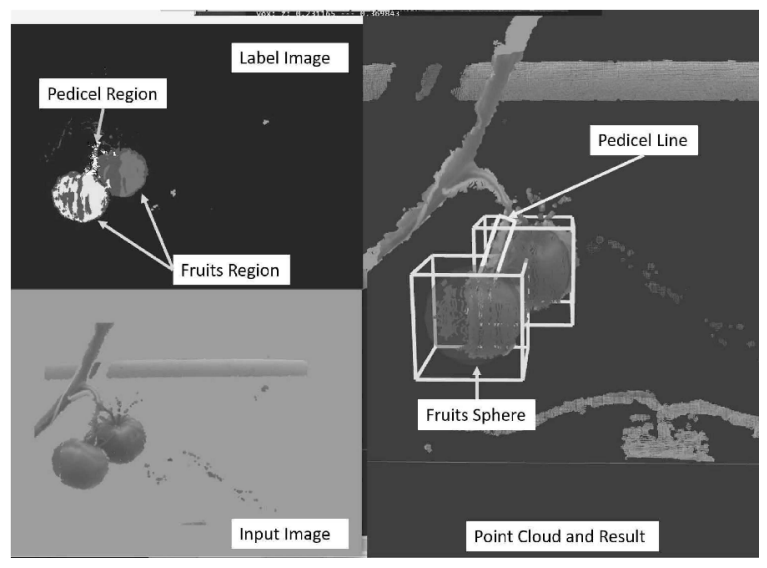

Fig. 17 Pedicel detection result for 2 tomatoes [7]

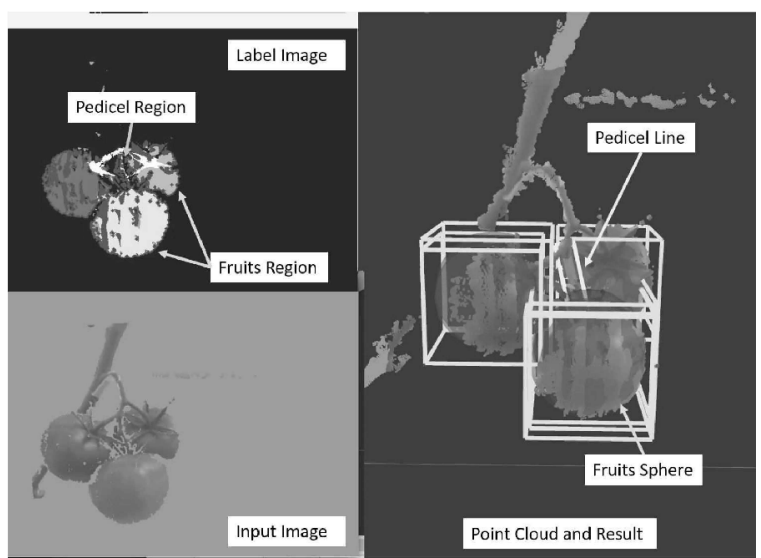

Fig. 18 Pedicel detection result for 3 tomatoes [7]

築し，実際のほ場に扔いて実物のトマトを対象とした評価実験 を行った。

実物のトマトは生育状況から大きさにばらつきがあり，色の 範囲も広い. また周囲には主茎をはじめとしたほかの植物体や 生育のための棚の部品などが存在する.ささらに光合成のために 日光を取り入れており，赤外線プロジェクタや受光部に影響し てノイズが大きくなるなどの問題点がある. Fig. 17 に果実が 二つの場合，Fig. 18 に果実が三つの場合の検出結果をそれぞ れ示す.いずれの場合も果実表面に縦縞上のノイズが発生して いるが果実を認識できて扔り，また隣接する果実の果柄やへ夕 に誘導されることなく果柄を検出することができている. 特に Fig. 18 の三つの果実の場合, 対象となる果実（左上部の中央に 示されている果実) の左右の果実の果柄とへタが顕著に抽出さ れているが，それらに誘導されず対象果実の果柄のみが検出さ れている.

検出器をロボットに適用し，収穫した様子を Fig. 19 に示す. はさみはより小型のものを新たに作りなおしたものであり，は さみ単体の収穫可能な要件として幅方向 $10[\mathrm{~mm}]$, 奥行き方向 $5[\mathrm{~mm}]$ の範囲でトマトの果柄にアプローチ寸る必要があるが, 今回の検出精度はそれを満足しており，収穫が可能であった。卜 マト一個あたりの収穫にかかる時間は抒およそ $10[\mathrm{~s}]$ 以内まで 短縮できた。これはもぎ取りと比べてはさみは刃を一度閉じる
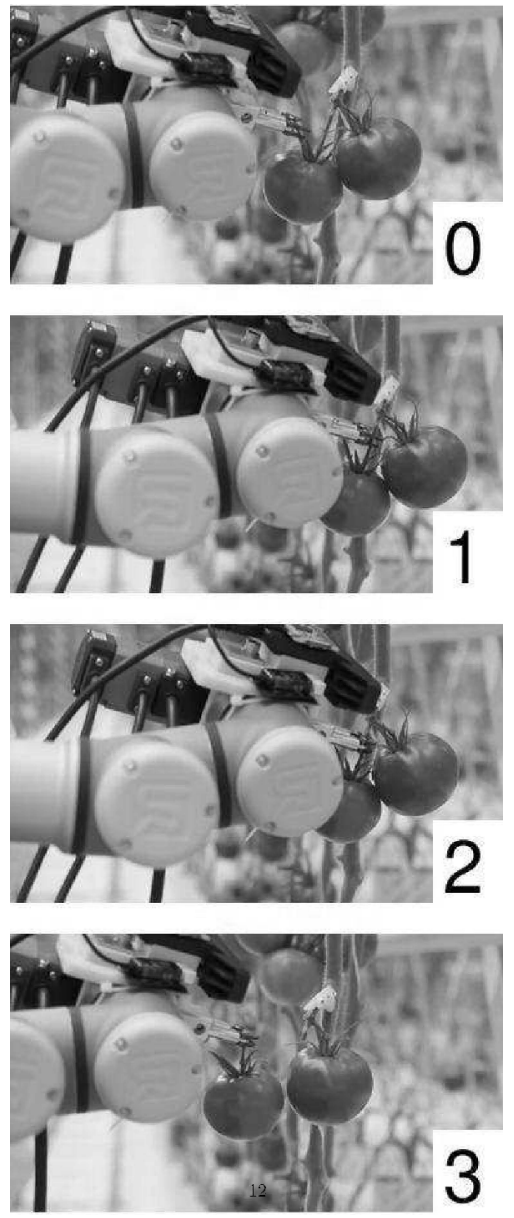

Fig. 19 Harvesting with scissor end effector [7]

だけで切断ができ，またはさみそのものを小型化したことで動 作ストロークが短くなったことと, アーム自体も小型のものを採 用したことで動作速度が改善したことが要因として挙げられる。

6. 4 トマト収穫に関する考察

最後にこれまでの一連の評価実験よりロボットシステムの比 較評価を行う。

第 6.1 節では汎用の人型ロボットプラットフォームに対して エンドエフェクタとセンサを取り付け，トマト収穫の実現性を 検討することを目的としていた．実験を通じて収穫ばさみを用 いたエンドエフェクタの実用性が明らかになったが，汎用のは さみがトマトに対して大きかったためにはさみの刃が果実を傷 つけるケースがあり，また収穫を続けるうちに刃こぼれが生じ て切れ味が低下し，適宜メンテナンスを行わないと上手く収穫 できないことが分かった。一方認識システムに関してはこの時 点では手動で行うものとし，全体の状況を理解する頭部カメラ と果実付近の状況を理解するハンドカメラが人間の操縦におい ては重要であることが分かった.

第 6.2 節では大型となりコストもかかる双腕ではなく単腕口 ボットとし，屋外対応のステレオカメラを頭部に該当する部分 に搭載した。またハンドカメラを要する切断ではなくもぎ取り 方式を採用し，果柄認識や切れ味の低下が問題とならないシス テムとした，果実認識を用いてもぎ取りハンドの位置決めを行 
う自動収穫システムを構築し，トマトの自動収穫に成功した。も ぎ取り方式では果実の破壊はなかったが，一方でへ夕が先に外 れてしまう，果柄に対して回転軸が最悪時 $90^{\circ}$ 近くずれてうま くもげない, という失敗があった. 前者は品種によって異なる 結果となり，もぎ取りに適した品種と適さない品種があること が分かった. 後者については文献 [4]のように重力方向にある程 度垂れることを期待した位置決めを行っていたが，実際のトマ トの生育状況を詳しく観察した結果, 重力方向と関係なく鉛直 に対し $90^{\circ}$ 近い角度で生ることも多いことが分かった。これに より，果柄認識の重要性が明らかとなった.

第 6.3 節では果柄認識を行うため, 第 6.1 節で有効とされた ハンドにカメラを設置するものとし，また収穫の確実性と第 6.1 節の問題点を考慮し, 小型のはさみを作りなおした. 全体的に 小型のハードウェアを用いたことで収穫速度が向上した. 特に これまでの実験から三つ以上の果実を持つ房では収穫成功率が 低かったが，Fig. 18 に示すように三つの果実を持つ房における 果柄認識が可能となり, 改善した. 一方ではさみの問題点であっ た定期的なメンテナンスの必要性, また SR300 の直射日光に対 する脆弱性といった問題が再発することとなった.

これら一連の実験の結果から, エンドエフェクタに関しては 切断ともぎ取りの双方にトレードオフがあり, 状況に応じた選 択がとれることが好ましいと考える。また認識のためのカメラ についても同様で，全体を俯瞰することと果柄のような細部の 観察を行うことを両立させるにはそれぞれに特化したセンサを 両方用いたほうが良い。認識については果実の分布のみではな く, 果柄認識を行うことで精度が向上し, 小さなはさみを用い た切断収穫も可能となった。

\section{7. 結論：トマト栽培システムの一部としての自動収穫}

本論文では自動トマト収穫ロボットの構成法として収穫装置 と認識手法の各要素について提案を行い, 実物のトマトや実際 のほ場での実験を通じて評価を行った，比較評価を通じて，で きる限り短いストロークで収穫できるロボットシステムと, 果 実と果柄に着目できる近接可能な三次元カメラを組み合わせる こと, 収穫対象である果実と切断対象である果柄の認識を同時 に行うこと, 品種の違いや個体差に応じて切断方式ともぎ取り 方式を選択すること, が収穫ロボットの構成において重要な点 であった，収穫装置ははさみともぎ取りの二形式を比較したが, 果実の破損の危険性と収穫の確実性の面でそれぞれに一長一短 があり，人手で行われているように品種や個体に応じた収穫装 置の選択が好ましい. 認識手法については果実認識と果柄認識 の手法を提案した，特に果柄認識が行えるようになったことでよ り信頼性の高いトマト果実の自動収穫を実現することができた. 果柄認識の実現のためには太さ $5[\mathrm{~mm}]$ の果柄を計測すること のできる三次元カメラが不可欠であるが，本論文で用いた Intel RealSense SR300 は日光が照射するビニールハウス内の条件で はやや計測が難しかった. また PlayStation Camera の評価に おいても $75,000[\mathrm{~lx}]$ が最大值であったが，晴天下で $100,000[\mathrm{~lx}]$ を超えることもあり，またダイナミックレンジに関しては照度 差も考慮する必要がある，晴天下における精密かつロバストな 計測は屋外作業ロボットにおいて重要な課題である。しかしな
がらビジョンセンサの進歩は日進月歩であり近く改善されるこ とが容易に予測され，なおかつ現状のシステムの範囲内であっ てもそもそもロボットの稼働する時間帯を日中からずらすなど の運用設計により解決は可能であると考えられる.

本研究の目標とするところは現状の実ほ場において生育され ているトマト果実に対し人間の代理となりうる収穫能力を実現 することであった，収穫速度の面において人間と比較すると，口 ボットは果実三つの房から 1 個あたり 10 秒での収穫を実現し た。対して人間の場合は 1 個あたり数秒のペースであり，また 収穫に際しては熟度による収穫判定も同時に行っている. 現状 のシステムは果実の色のみを使って収穫判定を行っている状態 だが，色や形状の情報がまとまったデータセットとして得られ れば三次元画像を用いた分類問題として定義でき, 既存の分類 手法が適用できる. 速度改善と熟度判定は技術的に容易に改善 できるものと考えられる一方で, 本論文ではトマト果実の収穫 に着目したが，トマト栽培においては他にも，生育状況に応じ た苗の再配置や葉かき，収穫した果実の搬送と選別など，現状 人手で行われており，ロボット技術の応用可能な要素が多数存 在する。これら栽培システムの一部をどのように自動化するか が次の技術的課題である，特に現代の農業は育成から収穫まで が一連のシステムとして設計されており，そのシステムの中で ロボットの適用限界を見極め, どのような役割で運用するかと いう運用設計が非常に重要である。

トマトに限らず農作物は生物であり, 個体差や品種の差といっ た条件もさることながら, 収穫時期が決まっているために気象 条件によって生育状況も左右される．特に 2016 年は 8 月の気 温が高く日照量が多かったにもかかわらず，9月に入り気温が下 がらずに日照量が低下した。この結果トマトが不作となり，評 価実験が思うように進まないという障壁もあった。農業にかか わるロボットの研究のためには, 対象となる農作物の知識や経 験が必要不可欠であるということが本研究における大切な知見 であった。

謝 辞 第 1 回および第 2 回トマトロボット競技会での実験 に際しては，競技会実行委員会の皆様に多大なるご協力をいた だきました，深く感謝申し上げます，また，第 1 回大会への参加 に当たっては, 東京大学大学院生の田中義丸君, Chen Xiangyu 君, Krishneel Chand Chaudhary 君, 佐藤顕治氏の協力をい ただきました。

\section{参 考 文 献}

[ 1 ] 池田英男 : “高生産性オランダトマト栽培の発展に見る環境・栽培技 術”, 日本学術会議公開シンポジウム「知能的太陽光植物工場」講演 要旨集, pp.32-41, 2009.

[ 2 ] 三輪泰史：“オランダ農業の競争力強化戦略を踏まえた日本農業の活 性化策”, JRI レビュー, vol.5, no.15, pp.106-118, 2014.

[3] 日本生気象学会：「日常生活に扔ける熱中症予防指針」ver.3 確定版, http://seikishou.jp/pdf/news/shishin.pdf, 2016.

[4] X. Chen, C.K. Chand, Y. Tanaka, K. Nagahama, H. Yaguchi, K. Okada and M. Inaba: "Reasoning-based vision recognition for agricultural humanoid robot toward tomato harvesting," Proc. of The 2015 IEEE/RSJ International Conference on Intelligent Robots and Systems, pp.6487-6494, 2015.

[5] 長濱虎太郎, 笹㴊一宏, 矢口裕明, 稲葉雅幸: “等身大人型ロボット プラットフォームを用いた農作業支援への取り組み〜トマトロボット 
競技会への参加を通して〜"，日本機械学会ロボティクス・メカトロ ニクス講演会'16 講演論文集, pp.2P2-17a1, 2016.

[6] H. Yaguchi, K. Nagahama, T. Hasegawa and M. Inaba: "Development of an autonomous tomato harvesting robot with rotational plucking gripper," Proc. of The 2016 IEEE/RSJ International Conference on Intelligent Robots and Systems, pp.652657, 2016.

[7] 矢口裕明, 長谷川貴巨, 稲葉雅幸 : “トマト収穫ロボットのための三 次元カメラを用いた果実・果柄認識手法”, 日本機械学会ロボティク ス・メカトロニクス講演会'17 講演論文集, pp.1A1-C01, 2017.

[8] S. Bachche: "Deliberation on design strategies of automatic harvesting systems: A survey," Robotics, vol.4, no.2, p.194, 2015.

[9] C. Blanes, M. Mellado, C. Ortiz and A. Valera: "Review. technologies for robot grippers in pick and place operations for fresh fruits and vegetables," Spanish Journal of Agricultural Research, vol.9, no.4, pp.1130-1141, 2011.

[10] M. Monta, N. Kondo and K.C. Ting: "End-effectors for tomato harvesting robot," Artificial Intelligence Review, vol.12, no.1, pp.11-25, 1998.

[11] S. Bachche and K. Oka: "Design, modeling and performance testing of end-effector for sweet pepper harvesting robot hand," J. of Robotics and Mechatronics, vol.25, no.4, pp.705-717, 2013.

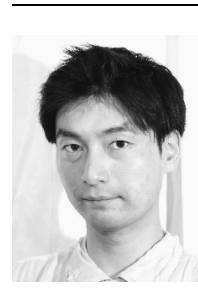

矢口裕明 (Hiroaki Yaguchi)

2004 年明治大学理工学部機械情報工学科卒業. 2009 年東京大学大学院情報理工学系研究科創造情報学専 攻博士課程修了. 博士 (情報理工学). 2008 年度下 期 IPA 未踏スーパークリエータ. 2009 年東京大学 特任助教, 2014 年特任講師. 2018 年よりクシナダ 機巧株式会社代表取締役社長. 社会実装を目的とし たロボットシステムインテグレーションに従事.

（日本ロボット学会正会員）

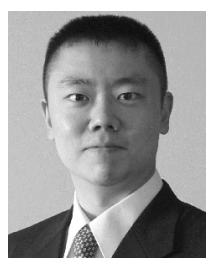

長濱虎太郎（Kotaro Nagahama）

2009 年東京大学工学部機械情報工学科卒業, 2014 年東京大学大学院情報理工学系研究科知能機械情報 学専攻博士課程修了. 博士 (情報理工学). 2014 年 より東京大学情報理工学系研究科創造情報学専攻特 任助教. 2017 年より 信州大学工学部講師. 生活支援 ロボット, 人型ロボットシステム, ロボットのための 観察学習システム等の研究・教育に従事.（日本ロボット学会正会員）
[12] S. Bachche and K. Oka: "Performance testing of thermal cutting systems for sweet pepper harvesting robot in greenhouse horticulture," Journal of System Design and Dynamics, vol.7, no.1, pp.36-51, 2013.

[13] パナソニック株式会社：農林水産業におけるロボット技術研究開発 事業/研究成果 3D センサを応用したトマト収穫ロボットの開発, 2018/2/5 18:00 閲覧.

[14] N. Kondo, K. Yamamoto, H. Shimizu, K. Yata, M. Kurita, T. Shiigi, M. Monta and T. Nishizu: "A machine vision system for tomato cluster harvesting robot," vol.2, pp.60-65. Asian Agricultural and Biological Engineering Association, 2009.

[15] H. Jiang, Y. Peng and Y. Ying: "Measurement of 3-d locations of ripe tomato by binocular stereo vision for tomato harvesting," 2008 Providence, Rhode Island, June 29-July 2, 2008, p.1. American Society of Agricultural and Biological Engineers, 2008.

[16] G. Feng, C. Qixin, N. Masateru, et al.: "Fruit detachment and classification method for strawberry harvesting robot," International Journal of Advanced Robotic Systems, vol.5, no.1, pp.41-48, 2008.

[17] 石井和男, 安川真輔，園田隆，李冰賀：“競技会を通じたトマト収穫口 ボットの開発”, 日本知能情報ファジイ学会ファジィシステムシンポジ ウム講演論文集第 31 回ファジィシステムシンポジウム, pp.167-170, 2015.

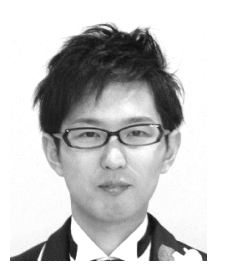

長谷川貴巨（Takaomi Hasegawa）

2006 年名古屋大学計算理工学部修士課程修了. 同 年株式会社デンソーに入社. 現在ロボットの画像処 理・統合制御の研究開発に従事.

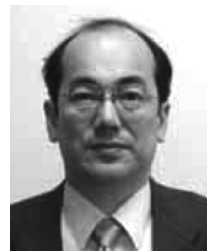

\section{稲葉雅幸（Masayuki Inaba）}

1981 年東京大学工学部機械工学科卒業, 1986 年東 京大学大学院情報工学専門課程博士課程修了 (工学 博士). 1986 年東京大学講師，助教授を経て，2000 年教授。知能ロボット，ヒューマノイドの研究教育 に従事.

(日本ロボット学会正会員) 